Open Access

\title{
The impact of wheat market liberalization on the seed industry's innovative capacity: an assessment of Brazil's experience
}

\author{
Larissa Flister ${ }^{1}$ and Viktoriya Galushko ${ }^{2^{*}}$
}

\author{
* Correspondence: \\ Viktoriya.galushko@uregina.ca \\ ${ }^{2}$ Department of Economics, \\ University of Regina, 3737 Wascana \\ Parkway, Regina, SK, Canada S4S 0A2 \\ Full list of author information is \\ available at the end of the article
}

\begin{abstract}
Market liberalization has a profound impact on the structure of economies as well as changes the roles of the public and private sectors and affects innovative capacity of countries. This paper explores the Brazilian experience with wheat market liberalization and the impact on the seed sector. The analysis presented in this paper is based on interviews with 12 experts intimately involved in wheat research and breeding in Brazil. The analysis reveals liberalization boosted private investment in wheat $R \& D$, which translated into increased research output. However, Brazil faced many challenges in establishing wheat innovation system and important lessons can be drawn from its experience.
\end{abstract}

Keywords: Wheat, Market liberalization, Innovation, Private R\&D, Qualitative analysis

\section{Background}

Wheat is the most commonly grown crop in the world ${ }^{1}$ occupying approximately $25 \%$ of the world's arable land and providing $20 \%$ of the daily protein and food calories for around 4.5 billion people (EMBRAPA 2014). With an estimated world population of nine billion by 2050, consumption of wheat is expected to increase by $60 \%$ (United Nations 2013; FAO 2012). This will require that annual wheat yield genetic gains rise from the present level of below $1 \%$ to at least $1.6 \%$ (FAO 2012). Such yield gains can only be achieved via sustainable research and breeding ${ }^{2}$ investments. Due to its complex genome, difficulties with hybridization, and regulatory barriers to introduce genetically modified wheat, private investment in wheat has been lagging in most countries. As a result, wheat research/breeding has been receiving substantial public funding support in many countries, however, this support has been on decline throughout the world. To ensure sustainable wheat research/breeding efforts, some countries already privatized wheat breeding and many are contemplating privatization to encourage innovation in the industry. This study will analyze the impact of market liberalization and subsequent privatization of research and breeding on the innovative capacity of the Brazil's wheat seed sector.

The existing literature on market liberalization ${ }^{3}$ in Brazil is generally concerned about the quantitative impact on poverty, prices, and trade volumes (Edwards 1993; Patel and Cassel 2003; Helfand 2003). Unlike the existing studies, we analyze the

(C) 2016 Flister and Galushko. Open Access This article is distributed under the terms of the Creative Commons Attribution 4.0 International License (http://creativecommons.org/licenses/by/4.0/), which permits unrestricted use, distribution, and reproduction in any medium, provided you give appropriate credit to the original author(s) and the source, provide a link to the Creative Commons license, and indicate if changes were made. 
situation within the context of the impact on innovation and employ a qualitative analysis. While some believe that a real-life story cannot be used to test a theory and to generalize, properly conducted qualitative studies can serve as valuable inputs into building a grounded theory (Strauss and Corbin 1990; Piore 2006) as well as better highlight the far-reaching implications of government policies and offer useful policy advice. The implications of structural reforms in the wheat market, including the privatization of wheat breeding and the changing roles of various institutions, are not well understood and are too broad, complex and unstructured for a quantitative study, thus reinforcing the vigour of qualitative analysis in researching the issue under consideration. In this study the analysis of secondary data is combined with expert interviews. The authors have interviewed 12 wheat breeders/scientists including five interviewees with more than 20 years of experience whose wheat research/breeding programs experienced first-hand the outcomes of liberalization.

Brazil can serve as an excellent case study to provide lessons for countries contemplating liberalization of agricultural markets. Brazil's privatization movement exemplifies how government intervention and liberalization can affect the wheat breeding industry in myriad ways, from R\&D to yields, quality, and adaptation. For decades, the government tightly controlled Brazil's wheat industry. Very strong protection of the domestic industry between 1985 and 1990 contributed to a significant expansion of wheat production with domestic production surpassing imports for the first time since 1961. Following the end of the military dictatorship in 1985, and subsequent democratization, the wheat market was opened up in the early 1990s. However, the opening of the market was not accompanied by public policies to support key stakeholders throughout the transition, and production declined steadily over subsequent years. Brazil, a country that witnessed a substantial increase in wheat production in 19851990, quickly returned to its pre-1985 production levels with wheat imports significantly exceeding domestic production of wheat in most years following liberalization.

The remainder of this paper is organized as follows. Section 2 highlights historical developments on the wheat market prior to liberalization and establishment of the private breeding industry. Section 3 provides a brief literature survey on the link between liberalization and innovation. Section 4 discusses the method of assessment. Section 5 presents the results and discussion. The final section concludes the analysis and draws a number of lessons for countries contemplating liberalization and privatization of crop research/breeding.

\section{Wheat market in brazil: background}

In the last century Brazil has since undergone many transformations in the wheat industry, ranging from heavy-handed government intervention to growing liberalization since the 1990s, which are briefly discussed below.

\section{The military dictatorship: 1964-1984}

In 1967, under the military dictatorship ${ }^{4}$ of Humberto de Alencar Castelo Branco, the government instituted Decree 210. This law unbound wheat prices in the domestic market from the international market and established stronger government controls over domestic production and imports of foreign wheat. The federal government 
became responsible for buying wheat from domestic producers, which was financed by the Bank of Brazil. All commercialization of wheat was subject to the rules set by the National Superintendency of Supply (SUNAB), and the transportation of domestic wheat received preferential treatment in all federal, state, and municipal companies. The extent of control was such that SUNAB was also responsible for determining the appropriate mix of wheat with any other bread-making flours.

Decree 210 also established that domestic wheat would take precedence over foreign wheat in the Brazilian market. It achieved this by imposing an annual quota on imports, which was set by SUNAB. In effect, the purchasing and selling of foreign wheat became a monopoly of the federal government, whose transactions were done through the Bank of Brazil's Portfolio of Foreign Trade. The costs of the import quotas were substantial: it is estimated that the government spent between US $\$ 2.20$ and US $\$ 2.43$ for every dollar of imports it barred (Knight 1972).

Along with regulatory changes, the government introduced a series of measures aimed at modernizing the agricultural system, one of which was creation of Brazilian Enterprise for Agricultural Research (EMBRAPA). EMBRAPA's contribution to wheat $R \& D$ in Brazil included (1) training of scientists in various areas, and (2) increased research collaboration to develop new varieties and broaden the genetic base of wheat (Wilkinson \& Sorj 1992).

By the 1980s, the dictatorship had come to a decline; elections were held in 1985 and a president was sworn. The move to democratic institutions was accompanied by an increase in civil and economic liberties, resulting in the emergence of freer markets and strongly reshaping the landscape of the Brazilian economy. These changes allowed some industries to thrive, while others failed and in the following we discuss the impact on the wheat market and innovative capacity of the seed sector.

\section{Market liberalization and innovation: a brief literature survey}

Market liberalization can have an impact on innovative capacity of the seed industry through a number of channels. The first channel involves knowledge spillovers and technology transfer. A number of studies have argued that trade facilitates the transfer of knowledge and ideas across countries (Grossman and Helpman 1991; Coe and Helpman 1995). More specifically, exposure to export markets brings firms into contact with international best practices and fosters learning (World Bank 1997; Clerides et al. 1998). Liberalization also opens the doors for private suppliers of seed and can therefore greatly increase technology transfer from abroad (Gisselquist and Pray 1999). Better access to the latest genetic advances in seed technology can broaden the germplasm/research base of the domestic breeding programs, thus boosting the seed industry's innovative capacity.

The second channel involves the link between trade openness and increased competition. The theoretical literature on the link between competition and $R \& D$ investment yields mixed results. Grossman and Helpman (1991) show that increased competition can reduce the market share of the firms in the industry, thus creating disincentives to increase R\&D investment. A number of studies, however, support the view that stronger competition encourages incumbent firms to invest more in $R \& D$ in order to maintain their leading positions (Aghion et al. 1997, 2001). In application to the seed market, Pray and Ramaswami (2001) find that economic liberalization in India transformed the seed industry and 
encouraged private investment in crop research and breeding. Lifting restrictions to and subsequent entry of foreign seed companies contributed to increased competitive pressures in the seed industry, thus forcing local firms to invest more in research to remain competitive.

Tambunan $(2007,2008)$ finds positive correlation between openness to trade and plant size suggesting that market liberalization forces inefficient firms out of the industry thus creating conditions for more efficient firms to grow and better exploit economies of scale. Economies of scale provide significant cost advantages in production and R\&D activities and are especially important in varietal development, which can encourage more seed innovation.

The third channel involves enlarged market effect. Through reduction of barriers to trade and technology flows between countries, the markets in which seed companies and farmers operate are drastically enlarged, thus increasing returns to $R \& D$ and stimulating innovation (Pray et al. 2011).

The results from the existing empirical and theoretical literature suggest that opening of an economy to foreign competition and trade creates incentives for private firms to engage more in $R \& D$ and thereby increases innovative capacity. Based on the insights from the related literature, the following hypotheses can be formulated for the seed industry: liberalization increases innovative capacity of the domestic seed industry through better access to foreign seed/technologies; liberalization increases private R\&D investment through enhanced competition; and, liberalization enhances private $R \& D$ due to firms growing bigger and better exploiting economies of scale.

\section{Methods}

For our analysis we consider publicly available data such as yields and R\&D investment. The analysis also heavily relies on qualitative data gathered through personal interviews with 12 members of the wheat research and breeding community in Brazil between March of 2014 and February of 2015. Approval from the University of Regina Research Ethics Board was obtained prior to contacting the potential interviewees.

The advantage of using a qualitative research method is that it gives us flexibility and freedom to explore a phenomenon in-depth (Strauss and Corbin 1990). The impact of wheat market liberalization in Brazil goes well beyond the observed changes such as changes in prices, production, yield, and $R \& D$ investment. The full impact of liberalization involves changes in the industry structure and the way different players interact with each other and adjust to new market conditions in the short- and long-run. These changes are too broad and unstructured for a quantitative study; soliciting the perception of experts deeply involved in the industry provides informed insight into the consequences of wheat market liberalization.

The individuals interviewed came from a variety of sectors, ranging from union representatives, workers at EMBRAPA, and other public institutions, university faculty, and members of major private companies running plant-breeding programs. Even though the number of interviewees may seem small, these participants represented associations that own over $72 \%$ of Brazilian wheat cultivars registered with the International Union for Protection of New Varieties of Plants (UPOV). Their professional profiles are summarized in Table 1. 
Table 1 Summary of the interviewees' profiles

\begin{tabular}{|c|c|c|c|}
\hline Respondent & $\begin{array}{l}\text { Number of years in wheat } \\
\text { research/breeding }\end{array}$ & Occupation, type of company & $\begin{array}{l}\text { Current role within institute/ } \\
\text { organization }\end{array}$ \\
\hline 1 & 10 years & $\begin{array}{l}\text { Federal University of Rio Grande do } \\
\text { Sul (UFRGS) }\end{array}$ & PhD Candidate \\
\hline 2 & 8 years & Brazilian private breeding company & Sales of new varieties \\
\hline 3 & 24 years & $\begin{array}{l}\text { Brazilian public breeding and research } \\
\text { institution }\end{array}$ & Wheat scientist \\
\hline 4 & 4 years & Brazilian private breeding association & Wheat scientist \\
\hline 5 & 3 years & Brazilian private breeding association & Sales \\
\hline 6 & 22 years & Union & Agronomic Engineer \\
\hline 7 & 4 years & Brazilian private breeding association & Engineer \\
\hline 8 & 7 years & $\begin{array}{l}\text { Brazilian state breeding and research } \\
\text { institution }\end{array}$ & Researcher \\
\hline 9 & 6 years & Brazilian private breeding company & Director \\
\hline 10 & 28 years & Brazilian private breeding company & Phytopathologist \\
\hline 11 & 50 years & Brazilian private breeding company & $\begin{array}{l}\text { Research and development } \\
\text { manager }\end{array}$ \\
\hline 12 & 33 years & $\begin{array}{l}\text { Brazilian public breeding and research } \\
\text { institution }\end{array}$ & Wheat scientist \\
\hline
\end{tabular}

Each interview lasted 1 to $2 \mathrm{~h}$; a copy of the questionnaire can be obtained from the authors upon request. Wheat researchers and breeders were encouraged to discuss the structure of the wheat research industry in Brazil and the effects of historical changes in the system. Furthermore, discussion took place around the roles of the public and private sectors, linkages between research institutions and breeding companies, aspects of public-private collaborations, the structure of research funding, commercialization of new wheat varieties, and IP rights. Additionally, the challenges the wheat industry is currently facing, and potential solutions to those challenges were addressed.

The data were analyzed using the Attride-Stirling analytic method that involves the reduction and the break-down of the text to identify themes and construct thematic networks, the exploration of the text, and the integration of the exploration The Attride-Stirling method is considered to be a robust technique for the systematization and analysis of qualitative data because each theme is explored in detail to find a pattern and structure that arise from the text (Attride-Stirling 2001). Those patterns are then used to provide grounded arguments for the original research questions. When applied to the Brazilian wheat research system, it provides a thorough evaluation of the collected qualitative data.

\section{Market liberalization, crop r\&d and innovation: results and discussion Wheat production, demand for seed, and R\&D investment}

The way in which the wheat industry and Brazil's economy in general were most profoundly impacted and reshaped by the emergence of freer markets was through the reduction of domestic prices. Between the end of the dictatorship, in 1986, and the opening of the Brazilian economy in the early 1990s, the domestic price of wheat decreased by $78 \%$. Furthermore, exposure to more efficient producers, such as Argentina, significantly impacted Brazilian wheat producers. The second half of the 
1980s was characterized by very heavy protection of the industry, which resulted in a substantial expansion of wheat production: between 1985 and 1989 wheat production more than doubled reaching its peak of slightly over 6 million tons in 1987, which was three times of the pre-1985 level. By 1991, production had fallen and returned to its pre-1985 level, and land devoted to wheat production fell by $42 \%$ compared to 1987 (M. Dias Branco 2014). That year, Brazil had to import $70 \%$ of wheat consumed domestically (M. Dias Branco 2014). Figure 1 presents the area devoted to wheat and quantity produced, between 1944 and 2012, while Fig. 2 shows wheat prices.

During the dictatorship the government purchased wheat at artificially high prices; however, as the aforementioned interviewees expounded, a more open economy exposed Brazilian producers to foreign competition, and high prices were thus no longer guaranteed. The government's official policy of self-sufficiency in wheat ended in 1990, leading to increases in imports. At that time, the cost, insurance, and freight (CIF) of importing wheat were low. The high global stock of wheat and the American government's subsidization of wheat exports were largely responsible for low global prices, and increased the appeal of foreign wheat to Brazilian purchasers. In spite of the sharp drop in prices brought by liberalization, Brazilian prices remained high in comparison to international prices, and millers consequently increased consumption of foreign wheat (Brum \& Müller 2008).

Although wheat price reduction benefitted consumers, it hurt producers. Liberalization made it more profitable for a considerable number of farmers to harvest other crops, leading to a continued decrease in wheat production, which returned to its pre-1985 level. As a consequence of decreased domestic prices and increased imports, producers sought government assistance once again shortly after liberalization. In response, the government adopted what is known in Portuguese as Prêmio para Escoamento de Produto (PEP) - a government subsidy that takes place through a public auction with the National Supply Company (CONAB) being made responsible for

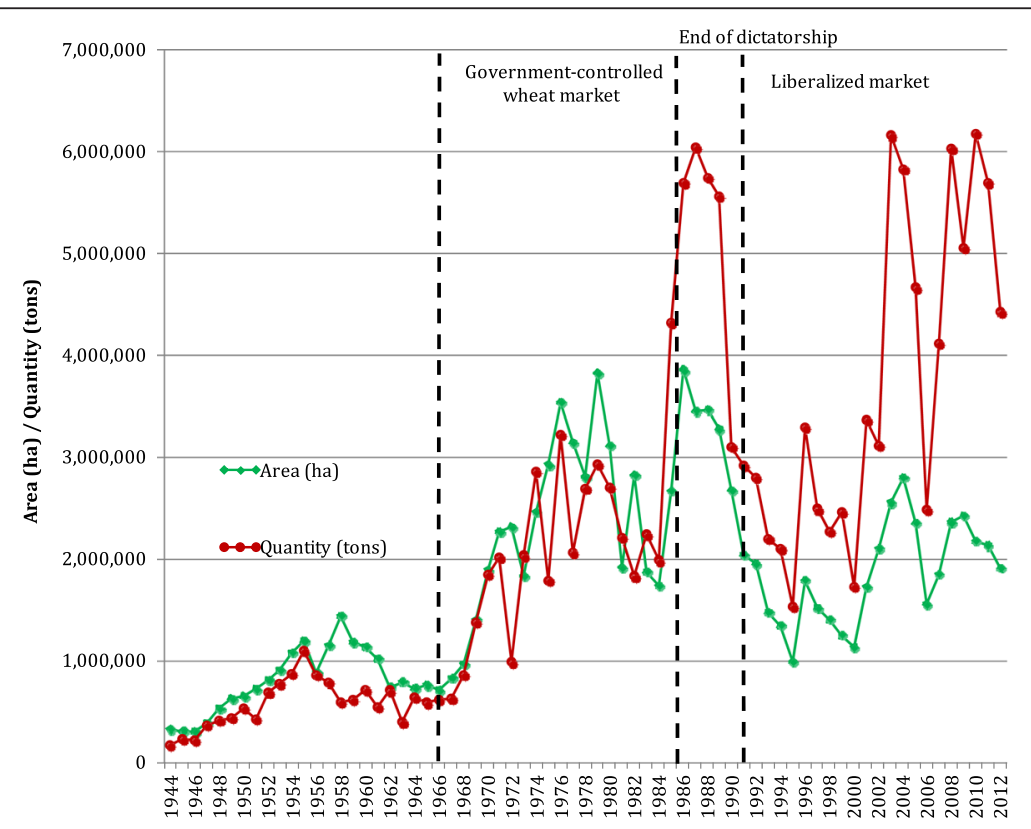

Fig. 1 Area and domestic production of Brazilian wheat, 1944-2012. Source: Author-generated based on IPEA (2014) 


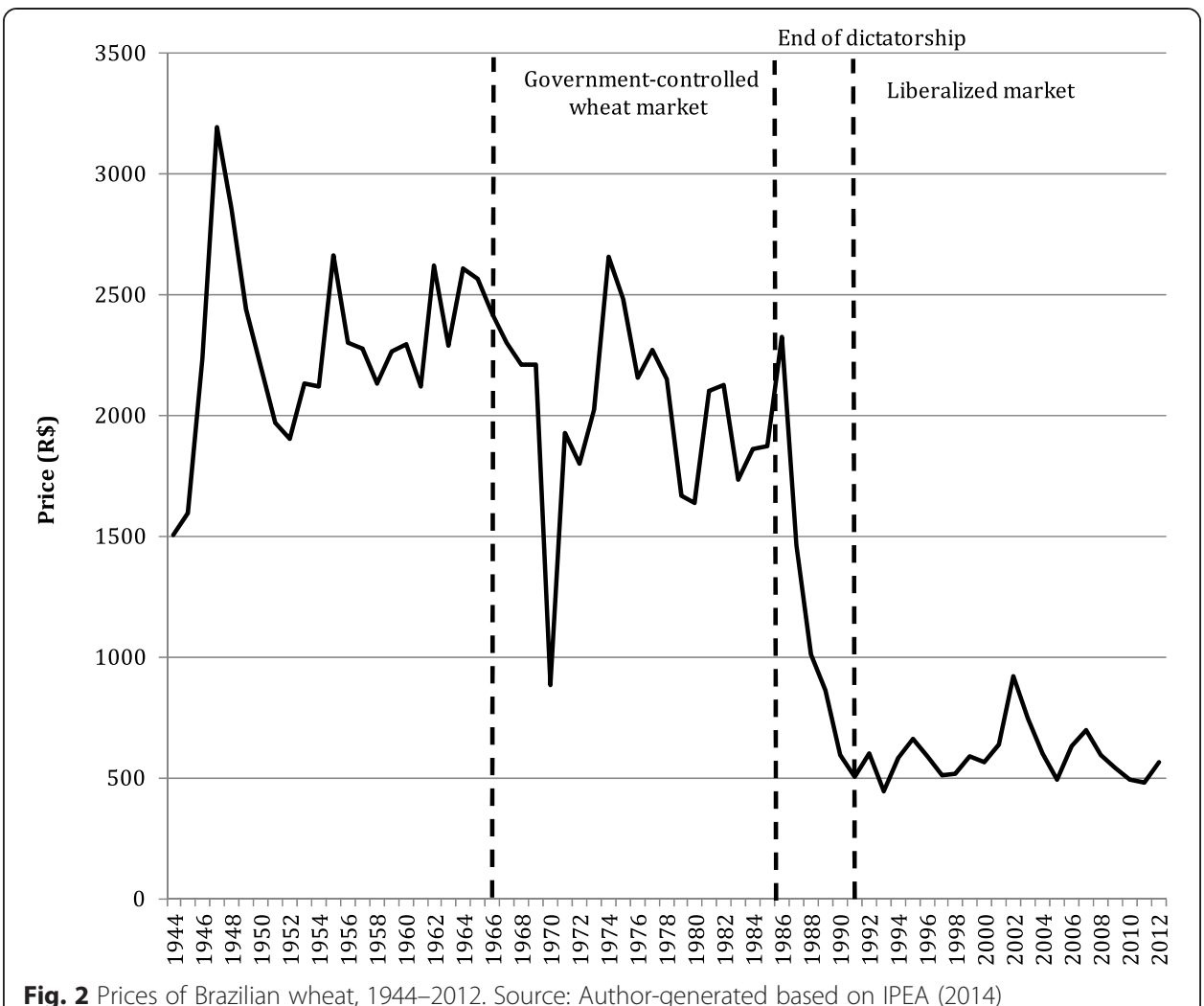

purchasing cereal. In such auctions, the government, through CONAB, offers a premium to those interested in purchasing products directly from producers at the government-set price. This premium amounts to the difference between the government-set price and the market price. The goal is to ensure a minimum price for producers, while avoiding the creation of surplus stocks. It also aims to direct products to regions that would otherwise have to import them, thus ensuring product flow throughout the country. In the early 1990s, the price set by CONAB for auctions through PEP was $32 \%$ below the world price: US\$94.52 per ton, in comparison to US $\$ 140.00^{5}$ (Brum \& Müller 2008). The reduction in domestic prices stimulated domestic demand, however, national production was undermined. Whereas in 1986 and 1987 the country was close to becoming self-sufficient, producing around 6.5 million tons of wheat annually, production dropped to around four million tons in the following years. It has since remained at that level, meeting around $50 \%$ of domestic demand (Caierão et al. 2012). This has led Brazil to become one of the largest importers of wheat in the world. Between 2011 and 2014, it was third only to Egypt and China, importing over 7.3 millions of tons of wheat annually.

One participant commented that reduction in wheat prices significantly reduced demand for seed and made wheat unattractive for the R\&D sector:

"This [liberalization] brought in more competition; however, there are also no longer any assurances of price floors and guaranteed purchases. This has led to a lot of variability and it affects quality because farmers are scared of making investments. They don't adopt the best system to cultivate wheat; it ends up just being something 
that farmers plant in the winter so their land is not empty. They'll later use the land for soy. So the issue is not developing the right kind of seeds - the problem is that there's no guarantee of profits. It limits investments. Farmers don't invest in recent seeds, fertilizers, and they at times don't even bother planting during the correct season".

\section{Plant intellectual property (IP) laws and royalty collection}

Following liberalization, Brazil also undertook measures to move towards stronger and robust IP protection. This move started with the country's decision to join the World Trade Organization (WTO) and become a party to the General Agreement on Tariffs and Trade (GATT). Following its move to comply with international regulations, on April 25, 1997, Brazil implemented Law No 9456, known as the Plant Variety Protection Law [PVP Law]. The PVP Law allowed breeders to collect seed royalties. Without the legal backing of the PVP Law private involvement in R\&D would have been scarce. This is evidenced by the lack of private sector research prior to 1997: no one, other than the public sector, was willing to invest in developing new cultivars.

In the Brazilian royalty collection system, plant breeders sell seeds to multipliers, who then sell them to seeders. Oftentimes, the same institution is a plant breeder and seed multiplier, in which case it sells directly to seeders. The seeders then pay approximately $8 \%$ of their revenue to the owner of the wheat variety. Last, seeders sell seeds to farmers, who, except in the exempt cases prescribed in the PVP Law, are not legally allowed to save seeds without paying royalties to the plant breeders. Figure 3 illustrates this royalty collection process.

The PVP Law exempts from royalty collection seeds that are used by breeders to develop new varieties, and seeds that are obtained by the government or by a private party (with government approval) in instances where such breach is justified by increased societal welfare. However, the most noteworthy exemption from royalty collection allowed by the PVP Law is that of seeds that are saved for "private use" (commonly known as farm-saved seeds), as prescribed in Article 10, Section 1 of the PVP Law. Generally, a farmer is not allowed to keep seeds for a long period, and is required to plant them on his or her property. Furthermore, the farmer is not allowed to sell the product of this harvest. These rules do not apply to family farmers, farmers who acquired land through agrarian reforms ${ }^{6}$ and indigenous Brazilians. Members of these groups are allowed to distribute, trade, and sell products harvested through farm-saved seeds amongst themselves. These

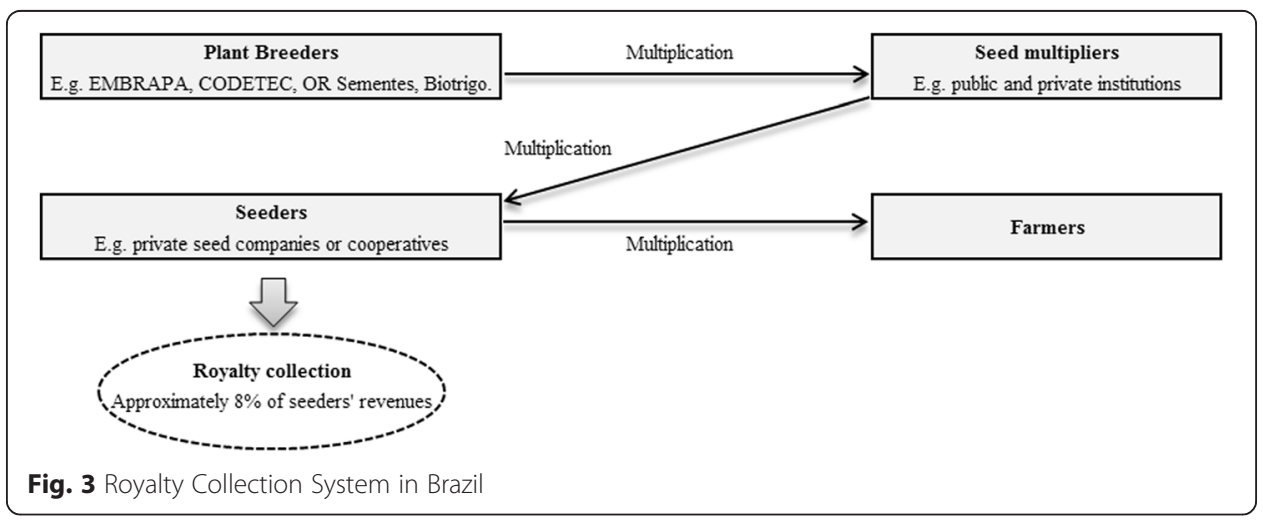


exemptions are glaring, given that these groups represent a significant proportion of the Brazilian agricultural sector. The latest census data available, published in 2006, indicated that family farms represented $84.4 \%$ of the total number of farms; utilizing $24.3 \%$ of land devoted to agriculture and employing $74.4 \%$ of workers in the sector (Government of Brazil 2014). Furthermore, in that year family farms accounted for $32 \%$ of the agricultural sector's GDP and $9 \%$ of the country's GDP (Government of Brazil 2014).

There is no doubt that the PVP law was very successful in increasing private R\&D investment in wheat. Prior to the PVP Law, new cultivars were developed almost entirely by the public sector, while currently the private sector accounts for almost $80 \%$ of the seed market. However, a number of challenges still exist for the private seed industry. One such challenge is the private use exemption in the PVP Law. According to one interviewee who works in the public sector, about $20 \%$ of the area is planted with farmer saved seed. This is close to the Brazilian Association of Seeds and Plants' (2009) estimate that royalties are not collected on approximately $28 \%$ of wheat seeds. Based on the royalty revenues reported by the private sector, farm saved seeds result in lost revenues for the breeders in the range of US $\$ 1.1 \mathrm{M}$ to US $\$ 1.7 \mathrm{M}$ annually.

\section{Transformation of the seed market and public-private partnerships}

Introduction of the PVP Law was the main driving force behind spurring private investment in wheat $R \& D$ and establishment of a strong wheat breeding private sector. National private breeding companies emerged as researchers were leaving the public sector to set up their own companies. For instance, the two biggest private companies in Brazil, OR Seeds and Biotrigo, were founded by ex-EMBRAPA researchers who left the public sector once the market was liberalized: one interviewee estimates that together OR Seeds and Biotrigo account for up to $70 \%$ of the seed market now. While ex-public sector researchers took advantage of their vast experience in wheat to start their own breeding programs, multinational corporations have not formally entered the Brazilian wheat market, although interviewees indicated that it is known that Nidera, Syngenta, Bayer, and Dow work with wheat improvement. According to one interviewee, two main reasons explain the absence of major multinationals in the wheat market. The first is that the area devoted to wheat is still too small to spark the interest of multinationals. Royalties are collected on around 5.8 million bushels of wheat per year, while another 2.5 million are sold in the brown bagged market. This amounts to about US $\$ 4.4$ million in royalties - a small amount in comparison to major crop markets, such as soybean and corn. The second reason is that Brazilian soil, which is rich in aluminum, and the country's climatic conditions make it difficult for multinationals to use the seeds developed elsewhere in Brazil. These peculiarities act as a barrier to multinational companies, restricting the Brazilian wheat market mainly to domestic companies, such as Biotrigo, OR Seeds, COODETEC, and EMBRAPA.

Currently, private companies and cooperatives dominate the domestic seed market: out of 186 varieties registered with UPOV, private companies and cooperatives own $67 \%$ of wheat varieties in Brazil. As noted by the interviewees, the market is rather concentrated with eight players owning $86 \%$ of varieties proposed or registered with UPOV. EMBRAPA still remains an active player in wheat research. Seed royalties are not sufficient for private companies to carry out basic research and as a result the 
private sector's budget is directed to more profitable ventures such as applied research and the development of new cultivars. Basic research is contracted out to universities and research institutes with EMBRAPA playing an active role in supporting wheat research. Of its annual budget of US $\$ 890$ million, it invests approximately US $\$ 15.5$ million, or 1.75 \% of its budget, on wheat R\&D (Sistema Brasileiro do Agronegocio 2013).

The establishment of the private research/breeding sector created a need for publicprivate partnerships (P3s). Partnerships were viewed by the interviewees as beneficial to the private sector and essential to maximize the public sector's research potential. Although they are perceived as important, P3s in wheat R\&D in Brazil are scarce. One reason for this stems from the public sector's negative experiences with partnerships. Legislative changes following the enactment of the PVP Law encouraged financial agreements between State Seed Producers Associations and diverse organizations in order to develop new cultivars across the country, primarily in support of breeding programs for wheat and soybeans. Although no contract breaches took place in the wheat market, early negative experiences in the soybean market resulted in a general hesitancy on the part of the public sector to engage in partnerships with the private sector. For instance, when the first agreement took place between the Mato Grosso Foundation and EMBRAPA for soybean cultivation in 1997, the public sector invested around US\$8 million in a project that resulted in the Mato Grosso Foundation stealing the genetic matrices of 20,000 plants from EMBRAPA (Estadao 2001; Istoe 2007). Once new seeds were developed, the Mato Grosso Foundation unilaterally ended the agreement, which led the Government, representing EMBRAPA, to judicially request that the Mato Grosso Foundation return the genetic matrices to EMBRAPA. While the Mato Grosso Foundation officially agreed to this, it returned fake matrices and planted EMBRAPA's genetic material in one of its farms (Estadao 2001; Istoe 2007). A financial settlement for a fraction of EMBRAPA's loss, US\$1.25 million, was reached, and the case subsequently evolved into a criminal trial (Istoe 2007).

While some improvements have been made in the area of partnerships, a considerable deficit still exists. According to information gathered in the interviews, currently there is private financing for EMBRAPA's wheat breeding improvement programs only in Paraná, São Paulo and Mato Grosso do Sul - two of the main producing states, Rio Grande do Sul and Santa Catarina, do not possess such private financing. Private funding comes from the Meridional Foundation, whose members are primarily seed multipliers and cooperatives from Paraná and São Paulo (Fundação Meridional 2014). The funding, which according to one interviewee is approximately US\$100,000/year, is used for value for cultivation and use (VCU) tests $^{7}$ and registering cultivars. In exchange for financial support, EMBRAPA licenses these cultivars exclusively to participating states. Non-participating states are not granted access to developments achieved through such partnerships. The agreement between EMBRAPA and the Meridional Foundation is an important step in encouraging more P3s, as decision makers in both the public and private sectors will likely be influenced by the outcomes of this partnership, which has the potential to overturn earlier negative experiences.

In the private sphere, P3s have been hindered by what is perceived to be a growing political interference within government institutions. A common observation amongst the interviewees was that growing political intervention within EMBRAPA is negatively affecting the organization's ability to remain competitive in the face of a growing 
private sector. While it is difficult to assess to what degree such intervention is real or perceived, the interviewees' views closely align with empirical studies that link underperformance in publicly-owned companies to interference from politicians who promote output and employment over profits and efficiency (Willner 2001; Shleifer \& Vishny 1994; Zeckhauser et al. 1989). The interviewees also expressed concern over what they perceived as excessive influence of unions within EMBRAPA and other public research institutions. This influence is exemplified by changes in recruitment processes. Positions that were previously staffed based on qualifications and meritocracy are currently awarded based on the completion of standardized tests. The interviewees indicated that this model often does not result in the recruitment of the most adequate candidates, as it relies on one's ability to perform on a test rather than their cumulative work experience and educational achievements. These politically-motivated changes, they expounded, have played a major role in changing the organization's key strategic areas. In addition to the effect such changes may have on the public sector's operations, the way in which they are seen by stakeholders in the private sector plays a significant role in determining their willingness to pursue P3s. As indicated by the interviewees, public perception that EMBRAPA is inefficiently run and has too many employees has led many partnerships to end, as breeders and farmers distance themselves from a politicized environment.

One interviewee shared that different goals combined with general mistrust lead companies to resist entering into partnerships and in general the interviewees perceived greater integration in coming years to be unlikely due to lax enforcement of IPRs law.

The lack of collaboration between the public and private sectors has not come without a price. According to one interviewee, in the decade following the PVP Law, EMBRAPA's failure to form partnerships with the private sector was a main factor behind the sharp drop in its market share in the wheat seed market. Lack of partnerships also prevents private sector companies from realizing their full potential.

\section{Research output of the transformed seed industry: impact on yields and quality}

The above discussion suggests that liberalization did lead to increased private investment in wheat research and breeding, which is in accordance with the hypotheses formulated in Section 3. Increased investment, however, is no guarantee that innovative capacity of the industry has improved. Unless these investments translate into better products we cannot associate increased R\&D with improved innovative capacity. A study of the UK wheat breeding industry, for example, did not reveal an association between increased private investment and wheat yields, which from the farmer's perspective is probably the most important measure of output of the breeding industry (Galushko and Gray 2014). Figure 4 shows average wheat yield in Brazil.

We performed a structural break test on the wheat yield data to test empirically if there was a structural break following the end of the military dictatorship in 1986. The null hypothesis is that average wheat yield has remained constant over the sample period. The algorithm of the structural break analysis applied to the wheat yield data is described in Bai and Perron (2003). The breakpoints if any are assumed unknown and are estimated using a dynamic programming approach. The sample period is divided into $m$ partitions and the partition that provides the lowest BIC criterion is chosen. 


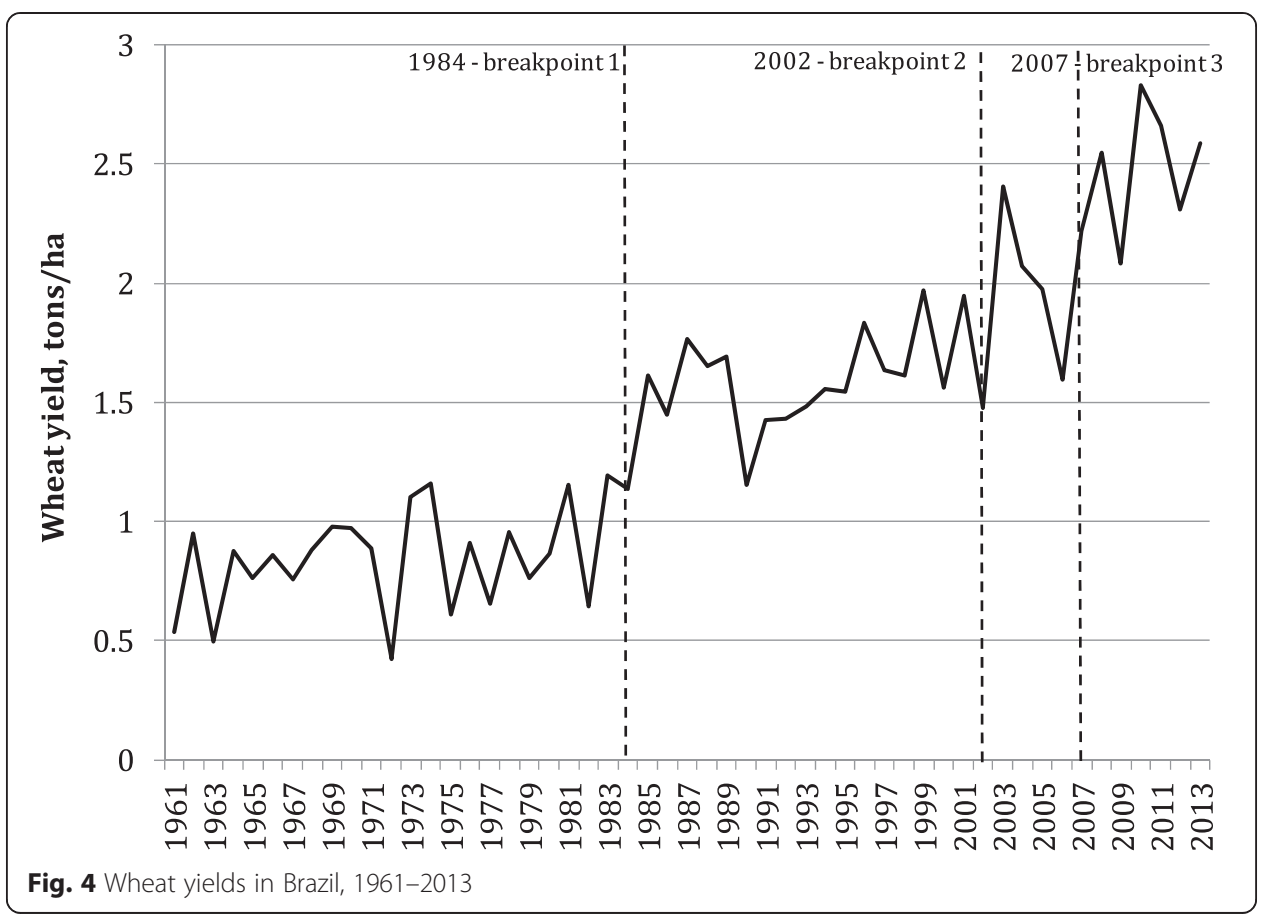

The structural break analysis is applied to (i) a model with the intercept only, and (2) a model that includes an intercept and a time trend. The former will reveal if there was a structural break in mean yields, while the latter will reveal if there was a structural break in trend. The estimation was performed in $R$ using the strucchange package. The results are reported in Table 2.

The results reveal that the partition with three breakpoints is the global minimizer. The significant change in the mean occurs at observation 24 (year 1984), 42 (year 2002), and 47 (year 2007). The breakpoints for the mean yield are shown in Fig. 3 above. The regression results, reported in Table 3 , indicate that mean yield significantly increased in post liberalization period.

The structural change analysis for the change in trend produced the minimum BIC at two breakpoints: observation 22 (year 1982) and observation 29 (year 1989). The results of the regression for the change in trend are reported in Table 4.

Table 2 The results of the break-point analysis: change in mean yield

\begin{tabular}{|c|c|c|c|c|c|c|c|c|c|c|}
\hline Breakpoints & Breakp & nts in $y$ & & & & & & & & $\mathrm{BIC}$ \\
\hline$m=0$ & & & & & & & & & & 106.00 \\
\hline$m=1$ & & & & 1984 & & & & & & 53.91 \\
\hline$m=2$ & & & & 1984 & & & & 2002 & & 22.50 \\
\hline$m=3$ & & & & 1984 & & & & 2002 & 2007 & 19.75 \\
\hline$m=4$ & & & & 1984 & & & 1995 & 2002 & 2007 & 24.05 \\
\hline$m=5$ & & 1972 & & 1984 & & & 1995 & 2002 & 2007 & 28.90 \\
\hline$m=6$ & & 1972 & & 1984 & 1989 & & 1995 & 2002 & 2007 & 34.03 \\
\hline$m=7$ & 1965 & & 1979 & 1984 & 1989 & & 1995 & 2002 & 2007 & 40.45 \\
\hline$m=8$ & 1967 & 1974 & 1979 & 1984 & 1989 & & 1995 & 2002 & 2007 & 47.10 \\
\hline$m=9$ & 1965 & 1971 & 1977 & 1982 & 1987 & 1992 & 1997 & 2002 & 2007 & 62.66 \\
\hline
\end{tabular}


Table 3 Regression results for structural break in means

\begin{tabular}{|c|c|}
\hline Variables & Estimated coefficient (standard error) \\
\hline Constant & $0.86(0.05)^{a}$ \\
\hline Constant*Dummy ${ }_{1984-2001}$ & $0.75(0.07)^{a}$ \\
\hline Constant*Dummy ${ }_{2002-2006}$ & $1.05(0.12)^{\mathrm{a}}$ \\
\hline Constant*Dummy $2007-2013$ & $1.61(0.10)^{a}$ \\
\hline Adjusted R-squared & 0.8622 \\
\hline
\end{tabular}

Note: ${ }^{a}$ means significant at $1 \%$

The analysis suggests that the wheat industry experienced a significant increase in the rate of yield gain between 1982, which is shortly before the end of the dictatorship, and 1989, which is immediately following the market liberalization reforms (see Fig. 5).

A rapid increase in wheat yields right after the end of dictatorship in 1984 can be explained by the fact that a lot of inefficient producers were forced to quit the wheat market. As is evidenced from Fig. 6, following market liberalization imports increased significantly, thus increasing competitive pressures for domestic wheat producers. It is also possible that some efficiency was gained due to increase in the scale of production. As is shown in Fig. 7, between 1985 and 2006 the overall number of farms increased, and while the number of small farms (less than 10 ha) dropped by $20 \%$, the number of larger farms dropped only by less than $10 \%$.

As the results of the above analysis suggest, liberalization of the wheat market had a positive impact on wheat yields in Brazil. However, it is difficult to isolate the impact of market liberalization on wheat yields from other impacts such as increased use of fertilizers and other variable inputs, exit of inefficient producers. As Fig. 8 reveals wheat yields seem to have been moving hand in hand with the intensity of fertilizer use measured by tones nutrients per hectare of arable land. However, since the data on fertilizer use by crop were not available, the results in Fig. 8 are based on the total consumption of fertilizers in Brazil. While this may be a good approximation of the intensity of fertilizer use in wheat production, given the available data we cannot say with certainty that the change in the rate of application of fertilizers was the same for wheat as for the major crops such as soy, corn, sugar cane, and coffee. Moreover, there is some evidence to suggest that the rate of fertilizer application in wheat production may have been growing at a slower rate than in other crops. Based on the information obtained from the International Fertilizer Industry Association database (2015), in wheat production fertilizer use increased from 0.126 nutrients per hectare in 2006 to 0.130 in 2011, which is a $3.1 \%$ growth. At the same time, the total fertilizer consumption increased from

Table 4 Regression results with two trend breakpoints

\begin{tabular}{|c|c|}
\hline Variables & Estimated coefficient (standard error) \\
\hline Constant & $-18.85(16.36)$ \\
\hline Constant*Dummy $_{1982-1988}$ & $-297.29(87.94)^{\mathrm{a}}$ \\
\hline Constant*Dummy $_{1989-2013}$ & $-81.69(20.76)^{\mathrm{a}}$ \\
\hline Time trend & $0.01(0.01)$ \\
\hline Time trend*Dummy ${ }_{1982-1988}$ & $0.15(0.04)^{a}$ \\
\hline Time trend*Dummy ${ }_{1989-2013}$ & $0.04(0.01)^{a}$ \\
\hline
\end{tabular}

Note: ${ }^{a}$ means significant at $1 \%$ 


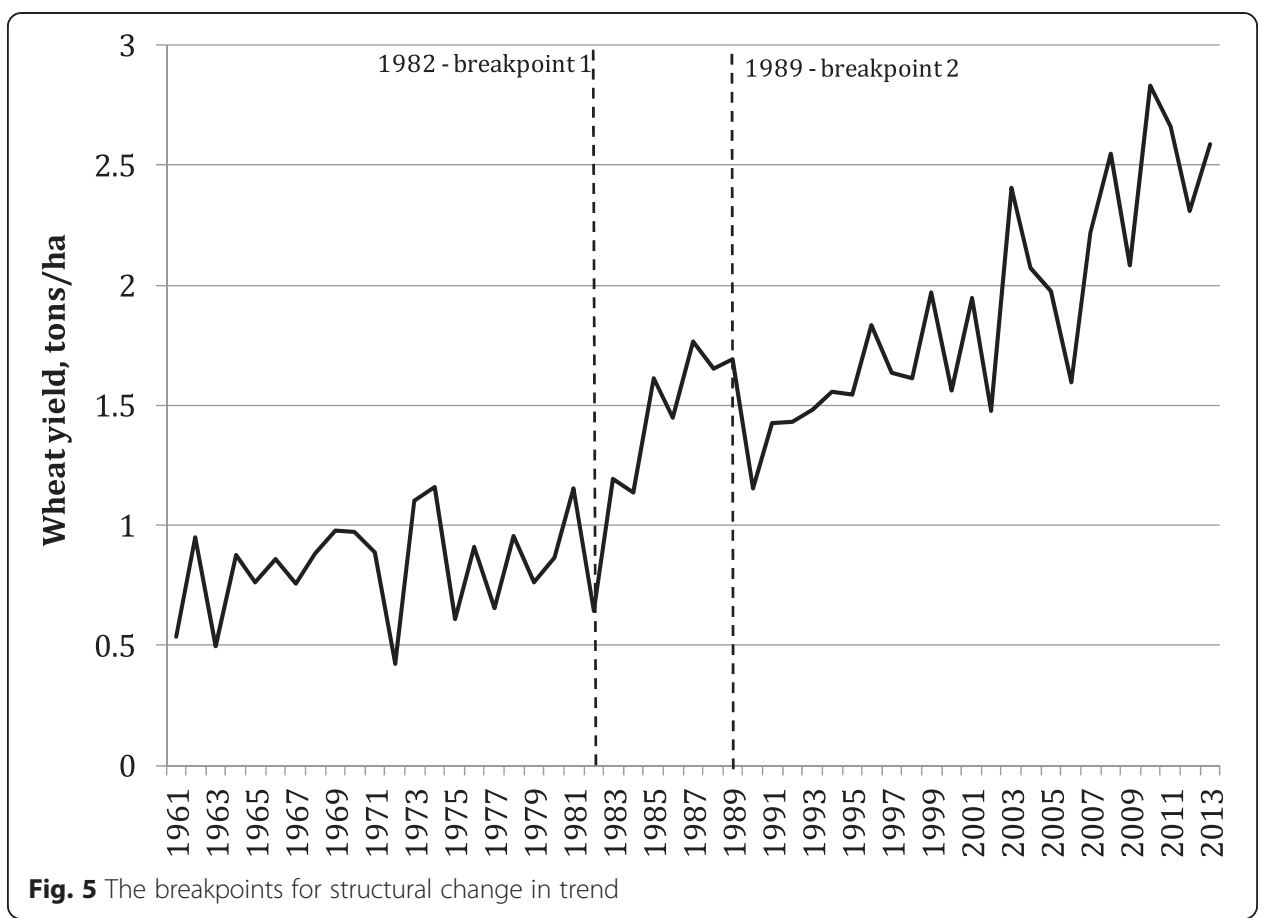

0.128 nutrients per hectare of arable land in 2006 to 0.161 in 2011, which is a $26 \%$ growth. Therefore, we do not have enough information to segregate the contribution of private R\&D investment, exit of inefficient producers, and increase in input use to increases in wheat yields. However, the interviewees agreed that market liberalization and subsequent increase in private investment was a significant contributor to genetic wheat yield gains.

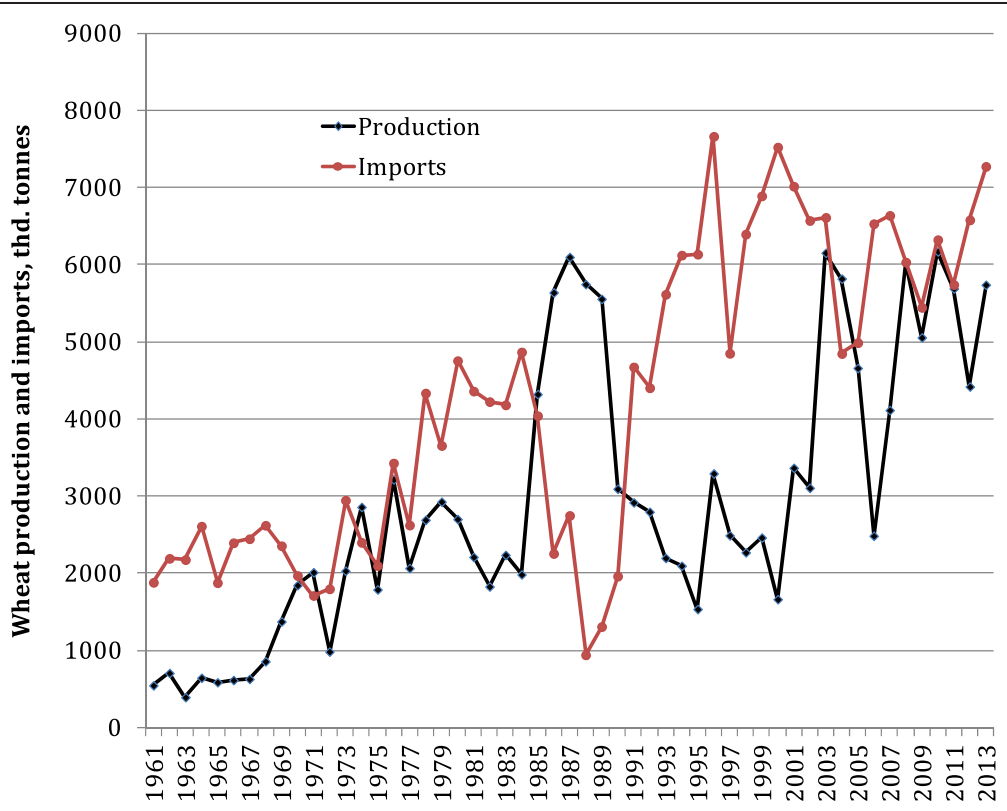

Fig. 6 Production and imports of wheat in Brazil 


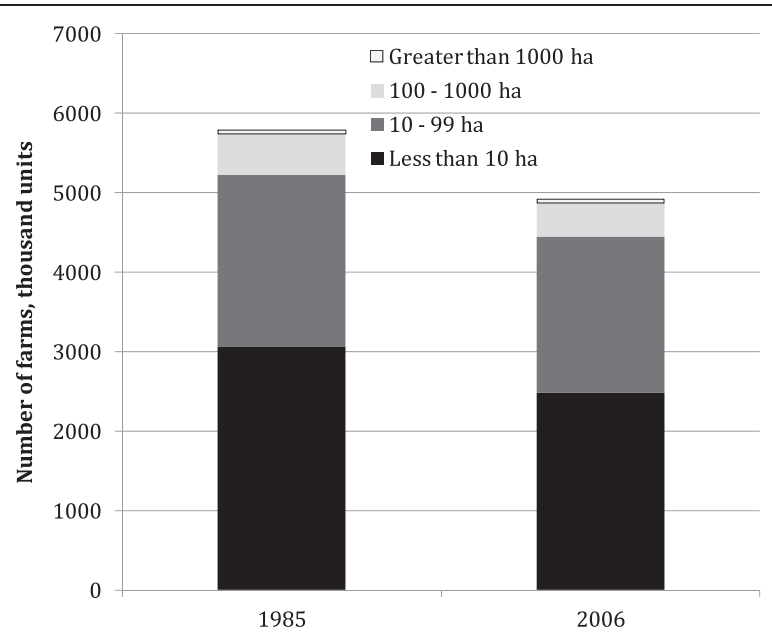

Fig. 7 Number of farms in Brazil, by size

Another measure to reflect output of the transformed wheat research/breeding industry would be quality of the grain produced. From the social point of view, quality improvements can significantly improve trade prospects and create new opportunities on the domestic grain market. Most of the participants agreed that breeding for quality has become much more important after the influx of private investment. One participant supported this by saying that Brazil is now building a reputation abroad for quality wheat.

\section{Post-liberalization challenges}

One of the challenges the wheat industry is currently facing is related to grain quality. While the R\&D sector has responded to the shift in end-user demand for higher quality wheat, a lot of farmers still focus on yields and do not place sufficient importance on quality. As a result, a lot of farmers choose to produce low-quality grain. As stated by

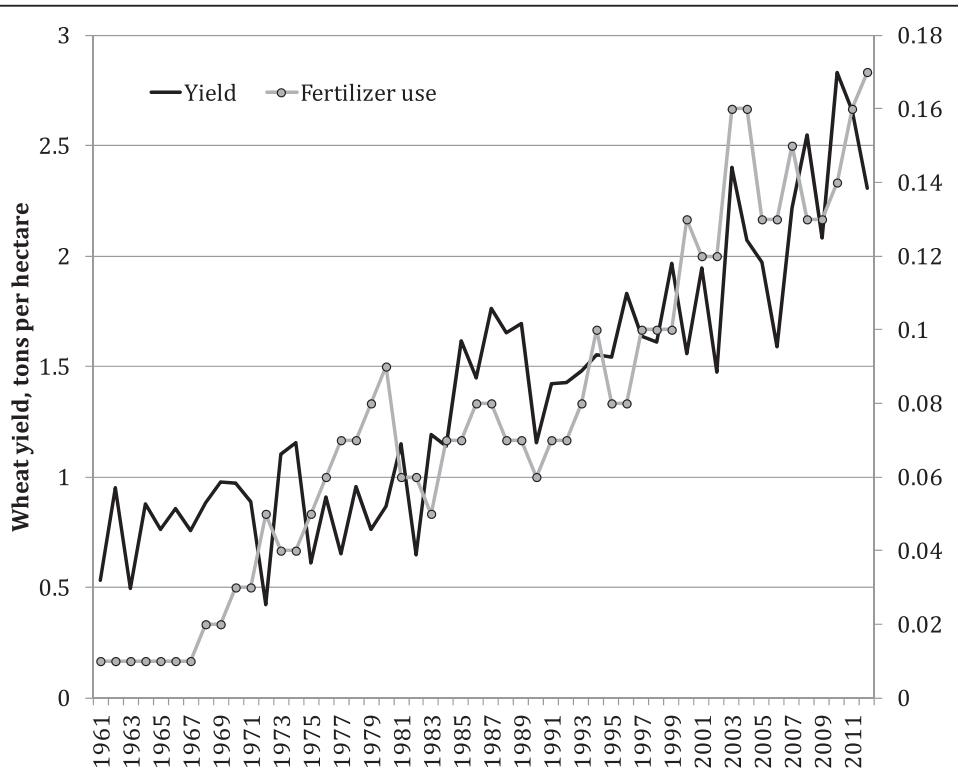


one interviewee, this poses a significant problem in farmers' cooperatives where grain of different quality produced by multiple farmers gets mixed together, thus reducing profits of those farmers who produced high-quality grain and could have earned a premium for better quality. Without a proper segregation system in place, there are disincentives for farmers to adopt new wheat varieties with improved quality and produce higher quality grain to meet the needs of the market. Therefore, the Brazilian government should design a policy and provide financial support to enable wheat segregation by quality. Without a well-functioning system of segregation by quality, the returns to research and breeding for quality will not be fully realized and the Brazilian wheat industry will not be able to compete with other South American and North American wheat producers that are known to produce grain of a much better quality.

The interviewees also mentioned that government regulations are not aligned with the potential of the seed research industry and end-users of grain (millers), which creates a bottleneck in the wheat supply chain. A number of interviewees expressed concerns that the minimum standards for each class of grain set by the government through Regulation RN38 do not reflect the minimum requirements of the milling industry. As a result, seed developers' efforts based off of Regulation RN38 do not address the needs of the milling industry. A three-way partnership, government - seed developers - millers, is required to design a policy framework that would ensure that the requirements of the market are met given the $R \& D$ sector potential.

The success of the wheat industry is hindered by lack of infrastructure to transport grain and interstate taxes. The participants of the study mentioned that if one is a miller in the North the current logistics makes imports of wheat cheaper than transporting grain from the South. High interstate taxes contribute to a substantial price differential, thus making foreign wheat more attractive to the milling industry. Also, as stated by some interviewees, the federal government policy has been such that duties on wheat imports can be waived while interstate taxes cannot be avoided, which creates additional incentives for millers to choose foreign wheat over the domestic one thus stifling the development of the domestic wheat industry.

It should be mentioned, however, that the above mentioned challenges are not unique to wheat. Problems of a lack of infrastructure and high interstate taxes are true for all agricultural commodities.

\section{Conclusions and policy options}

There are no doubts that liberalization had a profound impact on the wheat sector in general and wheat $R \& D$ sector in particular. Reduction in wheat prices following liberalization as producers were required to compete with foreign counterparts, turned wheat from a profitable commodity into an extremely risky and unprofitable crop that farmers would only use as a filler in their fields in winter when more profitable crops could not be grown. The opening of the economy was perceived by the interviewees as very sudden, which undermined wheat production and willingness of farmers to invest in wheat $R \& D$.

At the same time, liberalization and a move towards international plant IP protection standards encouraged private investment in wheat. Private $R \& D$ seems to have boosted the innovative capacity of the wheat research/breeding sector as reflected 
in higher yields of modern wheat varieties and more emphasis on research and breeding for quality.

Therefore, the Brazilian wheat research industry has experienced both successes and failures since liberalization and there are important lessons to be learned by other countries that contemplate reshaping their own wheat research/breeding sectors through liberalization and privatization.

Lesson 1 is that market liberalization may undermine production and as a result producer's willingness to fund research/breeding. Undertaking measures, following liberalization, that would support production of a crop is necessary for producer groups to invest in that crop. When inquired about the wheat industry's failure to mature, the interviewees did not mention lack of government intervention. Of the three main reasons cited, one was precisely excessive intervention in other areas of the economy, such as transportation and interstate taxes. In addition, insufficient credit availability to small- and medium-sized producers was noted as a significant constraint to the development of a strong wheat sector in Brazil.

Lesson 2 is that the public $R \& D$ sector may lose a significant level of human resources to the private sector. The private wheat breeding sector in Brazil emerged as researchers were leaving the public sector. However, overall, due to the EMBRAPA's human resources policy of aggressively developing the capacity of its researchers and significant investments in training, the public research agency managed to still maintain a critical mass of scientists despite the loss of researchers to the private sector (Correa and Schmidt 2014). While a transfer of human capital from the public to the private sector may increase collaboration and knowledge sharing between the two sectors through the network connections of former public employees, it may also have important implications for equity, efficiency, and public policy. The loss of applied scientists by the public sector may significantly reduce the efficiency through which scientific output is transformed into proof of concepts as applied research is separated from basic science. Therefore, a strong knowledge sharing mechanisms have to be in place to mitigate such losses, both within public institutions and between the public and private sectors. This leads to Lesson 3 that public-private partnerships are necessary to build a strong research industry and boost $R \& D$ potential.

Lesson 4 is that strong plant IP protection is required to facilitate development of the private crop $R \& D$ sector. The interviewees concurred that less exemptions from the PVP Law are needed to keep the private sector involved in R\&D. The Brazilian government has to do more work on finding a legal balance that ensures family agriculture remains affordable while preserving investments and developments in plant breeding.

Lesson 5 is that government involvement is required to establish a policy framework for segregation by quality and design regulations to assure quality grain for end-users. As the private research/breeding industry evolves post liberalization and responds to the end-users' needs by breeding for quality, it is important to create incentives for farmers to adopt those higher quality varieties. A decision to produce higher quality grain is contingent upon farmers' getting premiums for better quality, which necessitates an establishment of a well-functioning segregation system.

It should be borne in mind that the analysis presented in this study reflects the viewpoints of the experts intimately involved in wheat research and breeding; we have not interviewed farmers and millers to learn their perception of how liberalization of the 
wheat market has changed the industry's innovative capacity. Extending the study to include farmers' and millers' responses is left for future research. Surveying farmers could reveal more information as to why wheat became an unattractive crop and whether government policy could reverse that trend and somehow create incentives for producer groups to invest in R\&D. Also, surveying farmers and millers could shed some light on whether there is demand for higher quality wheat, which would provide direction for the breeding industry. Interviews with farmers could also elucidate their attitude towards stronger seed IP protection and give a better idea of the implications of removing the Family Farm exemption from the PVP Law.

\section{Endnotes}

${ }^{1}$ Wheat is number one in acreage. However, the tonnage of maize and rice harvested worldwide surpassed wheat in 1998/1999 (The Economist, 2005).

${ }^{2}$ Plant breeding is the art and science of changing the traits of plants in order to produce desired characteristics.

${ }^{3}$ The term "market liberalization" in the Brazilian context means much more than just trade liberalization. Economic liberalization involved a substantial restructuring of the economy including privatization of firms in many sectors of the economy, changes in fiscal discipline, fiscal reform, establishment of competitive exchange rates, trade liberalization, elimination of barriers to foreign direct investment, and financial liberalization. Throughout this paper, however, the term market liberalization refers to the policy changes that most directly liberalized trade.

${ }^{4}$ The term dictatorship is somewhat loosely used to describe the military period in Brazil that had some unique aspects differentiating it from other dictatorial periods: there was no single dictator, elections, albeit not fully free, were held at different levels of government throughout the period, and a gradual political liberalization began in 1974. Literature on the period of 1964-1984 in Brazil uses both terms (dictatorship and military period); however, the authors have chosen the first as this period was not, by modern standards, a democratic one.

${ }^{5}$ Not all wheat was purchased through CONAB's auction system. When purchased through unsubsidized sales, domestic wheat was oftentimes more expensive than foreign wheat.

${ }^{6}$ The Brazilian Government has authority to expropriate agricultural land that does not fulfill its "social function". As of 2013, by means of land expropriation or purchase, the government had redistributed agricultural land to approximately 1.3 million families (INCRA, 2014).

${ }^{7} \mathrm{VCU}$ tests evaluate differences of productivity, quality, as well as biological, chemical and technological characteristics from the standard variety, resistance to pests and diseases, and additional relevant characteristics for commercialization. 


\section{Acknowledgements}

This study was funded by Genome Canada and Genome Prairie (grant number 2313). The authors would like to thank the participants of the study for their time and willingness to speak with the authors about the development of the wheat (seed) industry in Brazil.

\section{Author details}

'Department of Economics, Applied Economics and Policy Analysis (MAEPA) program, University of Regina, 3737 Wascana Parkway, Regina, SK, Canada S4S 0A2. ${ }^{2}$ Department of Economics, University of Regina, 3737 Wascana Parkway, Regina, SK, Canada S4S OA2.

Received: 17 June 2015 Accepted: 30 March 2016

Published online: 11 April 2016

\section{References}

Aghion P, Harris C, Vickers J (1997) Competition and Growth with Step-by-Step Innovation: An Example. Eur Econ Rev 41(3-5):771-782

Aghion P, Harris C, Howitt P, Vickers J (2001) Competition, Imitation and Growth with Step-by-Step Innovation. Rev Econ Stud 68:467-492

Attride-Stirling J (2001) Thematic Networks: an Analytic Tool for Qualitative Research. Qual Res 1(3):385-405

Bai J, Perron P (2003) Computation and Analysis of Multiple Structural Change Models. J Appl Econ 18:1-22

Brum AL, Müller PK (2008) A realidade da cadeia do trigo no Brasil: o elo produtores/cooperativas. Rev Econ Socio Rural 46(1):145-169

Caierão E, Scheeren LP, Silva MS, Castro RL, Cargnin A, Moresco E (2012) Wheat in Brazil - the 2011 crop year. Annual Wheat Newsletter 58:67-68

Clerides SK, Lach S, Tybout JR (1998) Is Learning by Exporting Important? Micro-Dynamic Evidence from Colombia, Mexico, and Morocco. Q J Econ 113(3):903-947

Coe D, Helpman E (1995) International R\&D Spillovers. Eur Econ Rev 39:859-887

Correa P, Schmidt C (2014) Public Research Organizations and Agricultural Development in Brazil: How Did EMBRAPA Get It Right? World Bank, Economic Premise, June 2014, Number 145., Available via, http://siteresources.worldbank org/EXTPREMNET/Resources/EP145.pdf. Accessed 27 Jan 2016

Dias Branco M (2014) Mercado de Biscoitos, Massas e Grãos. Available at http://ri.mdiasbranco.com.br/mdiasbranco/ web/conteudo_pt.asp?idioma=0\&conta=28\&tipo=3003\#3. Accessed 9 March 2015

Edwards S (1993) Openness, Trade Liberalization, and Growth in Developing Countries. J Econ Lit 31(3):1358-1393

EMBRAPA (2014) Trigo.

Estadao (2001) Fundacao Mato Grosso Acusada de Roubar Matrizes da Embrapa

FAO (2012) Breakout session P1.1 National Food Security - The Wheat Initiative - an International Research Initiative for Wheat Improvement

Fundação Meridional (2014) Nossos Colaboradores., Available at http://www.fundacaomeridional.combr/. Accessed 12 Feb 2015

Galushko V, Gray R (2014) Twenty Five Years of Private Wheat Breeding in the UK: Lessons for Other Countries. Sci Public Policy 41(6):765-779

Gisselquist D, Pray C (1999) Deregulating Technology Transfer in Agriculture: Reform's Impact on Turkey in the 1980s. World Bank, Development Research Group, Policy Research Working Paper WPS2086. Available from http://papers. ssrn.com/sol3/papers.cfm?abstract_id=614976

Government of Brazil (2014) Agricultura Familiar no Brasil. Available via Ano Internacional da Agricultura Familiar, Camponesa e Indígena., http://www.aiaf2014.gov.br/aiaf/agricultura-familiar. Accessed 7 Jan 2015

Grossman G, Helpman E (1991) Innovation and Growth in the World Economy. MIT Press, Cambridge, MA

Helfand S (2003) The Impact of Agricultural Policy Reforms on the Agricultural Sector in Brazil in the 1990s: Implications for Pro-Poor Agricultural Policies. Paper presented at OECD Global Forum on Agriculture, Paris, 10-11 December, 2013

International Fertilizer Industry Association database (2015). Available via http://ifadata.fertilizer.org/ucSearch.aspx. Accessed 26 Jan 2016

IPEA (2014) IPEADATA. Available via IPEADATA: http://www.ipeadata.gov.br. Accessed 28 Aug 2014

Istoe (2007). Odilio, o encrencado. Available at http://www.istoe.com.br/reportagens/2015_ODILIO+O+ENCRENCADO. Accessed 12 Feb 2015

Knight PT (1972) Substituição de Importações na Agricultura Brasileira: a Producao de Trigo no Rio Grande do Sul. Rev Bras Econ 26(2):1-32

Patel R, Cassel A (2003) Agricultural trade Liberalization and Brazil's Rural Poor: Consolidating Inequality. Institute for Food and Development Policy, Policy Brief No. 8. Available from https://www.unc.edu/courses/2006spring/geog/ 021/001/08agribrazil.pdf

Piore MJ (2006) Qualitative Research: Does it Fit in Economics? Eur Manag Rev 3(1):17-23

Pray C, Ramaswami B (2001) Liberalization's Impact on the Indian Seed Industry: Competition, Research, and Impact on Farmers. Int Food Agribusiness Manage Rev 2(3/4):407-420

Pray C, Gisselquist D, Nagarajan L (2011) Private Investment in Agricultural Research and Technology Transfer in Africa. Paper presented at the ASTI/IFPRI-FARA Conference, Accra, Ghana

Shleifer A, Vishny RW (1994) Politicians and Firms. Q J Econ 109(4):995-1025

Sistema Brasileiro do Agronegocio (2013) Domínio nacional na área de sementes de trigo

Strauss A, Corbin J (1990) Basics of Qualitative Research. SAGE Publications, Newburry Park, California

Tambunan TTH (2007) Trade and investment liberalization effects on small and medium-sized enterprise development: a literature survey and case study of Indonesia. In: UNESCAP (ed) Towards coherent policy frameworks: Understanding trade and investment linkages. Studies in trade and investment No. 62. UNESCAP, Bangkok 
Tambunan TTH (2008) Trade Liberalization Effects on the Development of Small and Medium-sized Enterprises in Indonesia: A Case Study. Asia-Pacific Dev J 15(2):35-59

United Nations (2013) World Population Prospects. United Nations, Department of Economic and Social Affairs, Population Division

Wilkinson J, Sorj B (1992) Structural Adjustment and the Institutional Dimensions of Agricultural Research and Development in Brazil: Soybeans, Wheat and Sugar Cane. OECD Development Centre, Working Paper No. 76

Willner J (2001) Ownership, Efficiency, and Political Interference. Eur J Polit Econ 17(4):723-748. http://www.oecd.org/ dev/1919284.pdf

World Bank (1997) World Development Report 1997: The State in a Changing World. Oxford University Press, New York Zeckhauser R, Horn M, Murphy K, Paltzman S (1989) The Control and Performance of State-Owned Enterprises.

Rochester Stud Econ Policy Issues 6:7-75

\section{Submit your manuscript to a SpringerOpen ${ }^{\circ}$ journal and benefit from:}

- Convenient online submission

- Rigorous peer review

- Immediate publication on acceptance

- Open access: articles freely available online

- High visibility within the field

- Retaining the copyright to your article

Submit your next manuscript at $>$ springeropen.com 